\title{
A Descriptive Study on Awareness and Knowledge of Small Business Budget in Selangor
}

\begin{abstract}
Budget is a quantified financial planning for a future accounting period. It concerns with the middle and long term plan for the year ahead. Budgets are a clear indication of what is expected to be achieved during the budget period. Budget preparation also motivating managers to strive in achieving the organizational goals, controlling activities and evaluating the performance of managers. Budget is not only useful to the well-established organization but actually it is important for small scale business. 160 set of questionnaires were distributed to the small businesses manager/owner in the state of Selangor to get their level of awareness and knowledge on budgeting. From the study, it was found that the awareness and knowledge level of small businesses owner on budget is in moderate pattern. Future studies could enhance to the awareness and knowledge level of the medium size organization on budget.
\end{abstract}

Shuhaimi Jaafar, Nor Suhaily Bakar, Norsuriana Awaluddin

Kolej Universiti Islam Antarabangsa Selangor, Bandar Seri Putra, Bangi 43000 Kajang, Selangor, Malaysia shuhaimi@kuis.edu.my, norsuhaily@kuis.edu.my, suriana@kuis.edu.my

Keyword: Budgetting, Small Business, Awareness, Knowledge

\section{Introduction}

Budget is an important concept in microeconomic. To the small business, a budget is an organizational plan stated in monetary terms. Budget helps to aid the planning of actual operations by forcing managers to consider how the conditions might change and what steps should be taken now and by encouraging managers to considers problems before they arise. It also helps co-ordinate the activities of the organization. Budget works as tools to provide a forecast of revenue and expenditures; that is to construct a model of how a business might perform financially if certain strategies, events and plans are carried out. It also enable the actual financial operation of the business to be measured against the forecast. It also establish the cost constraint for a project, program or operations. Hence, with all the budget functions, the study of budget on awareness and knowledge of small business owner/manager is the right move towards a better business environment for the country.

\section{Budget and Small Business Literatures}

Small businesses are common in many countries. Small businesses are normally privately owned company, sole proprietorship or partnerships. Small businesses are small in size, easy to set-up, less capital and owner-managed. Examples of small business include food and beverages, grocery store, convenience store, small shops (bakery, café, etc), photographers, hairdressers, stall owners and a lot others. Small business also facing some kind of constraints such as under-capital, small sales, high insurance cost and others. In some countries such as United Kingdom and Australia, small business owners tend to be more concerned with excessive governmental red tape.

The small business definition is varies by countries. There is no global definition of small business. In the United States the Small Business Administration establishes small size standards on an industry by industry basis, but generally specifies a small business as having fewer than 250 employees for manufacturing and less than $\$ 7$ million in annual receipts for most non-manufacturing business. The European Union generally defines a small business as one that has fewer than 50 employees. In Australia, a small business is defined by the Fair Work Act 2009 as one with fewer than 15 employees. In addition to number of employees, other methods used to classify small companies include annual sales (turnover), value of assets and net profit (balance sheet) alone or by mixed definition.

Ministry of International Trade and Industry (MITI) of Malaysia, defined small business as a business with paid-up capital not more than RM500 000. Majlis Amanah Rakyat (MARA) defined small business as a business with paid in capital not more than RM200 000. Credit Guarantee Corporation (CGC), however defined small business as a business with paid-up capital not more than RM100 000 . Starting 1 January 2014, SME Corporation has defined small business as an organization with sales between RM300 000 to RM15 000000 or organization with employees between 5 to 75 (manufacturing) and 5 to 30 employees (other than manufacturing).

Records have shown that about $85 \%$ to $91 \%$ of business organization in Singapore, Taiwan, Thailand and South Korea are small businesses. In the United States of America 95\% of the business organization is small businesses. Meanwhile in Malaysia, the small businesses is more than $75 \%$ of registered businesses (Moha Asri et al, 2000). Small businesses are important to any economy as it employs many local people and benefits the country economic position as the money from the businesses stays in locally.

In 1971, Malaysian government had implemented Dasar Ekonomi Baru which strengthen on the involvement especially the Malay Bumiputera in business sector. Therefore several government agencies had been set-up accordingly such as Majlis Amanah Rakyat (MARA), Small Medium Industrial Development Corporation (SMIDEC), Ministry of 
International Trade and Industry (MITI), Perbadanan Nasional (PNS) and Yayasan Tekun Nasional (YTN). A part of that, there are funds created to help those small traders such as Tabung Ekonomi Kumpulan Usaha Niaga (TEKUN), Skim Jaminan Usahawan Kecil (Small Entrepreneur Guarantee Scheme) and Skim Pembiayaan Franchais (Franchise Financing Scheme). In addition, Bank Industri Malaysia Berhad was established in 1979 and later renamed to SME Bank in 2005 as a one-stop financial centre in responding to the to the funding and the business growth needs of small business in Malaysia. Currently, in the Rancangan Malaysia Kesembilan (Ninth Malaysia Plan), the small businesses are encouraged to upgrade and receive modern business practices to accelerate business integration with trading systems evolving in an efficient and competitive in line with the principles of competition and fair trade. In other words, the economic development of a country depends on the business development such as small business. However all the opportunities and initiatives prepared by the government becomes useless if there is no commitments among the trader to increase their awareness and knowledge in business tools and methods especially on budgeting.

A budget is a quantitative expression of an organization for a period of time. It may include planned sales volumes and revenues, resource quantities, costs and expenses, assets and liabilities and cash flows (CIMA, 2005). It expresses strategic plans of business units, organizations, activities or events in measurable terms. It serve a number of useful purposes including planning daily and annual operations, coordinating the activities of the various parts of the organization and ensuring that the parts are in harmony with each other. Blondal (2006) quoted that budget is among the four "pillars" in the public finance system in Singapore besides government investment agencies, Central Provident Fund and other various special funds. Large and complex organizations use budgets as one of their primary tools to manage and control their operations (Cress and Pettijohn 1985, Welker and Magner 1994). The budgeting process encompass formal and informal activities that take place during the preparation, implementation and application of the budget. A budget serves as resource allocation plan to coordinate organizational activities and communicate organizational goals and objectives to responsibility center. It can be used as a device to monitor, control and evaluate individual and organizational performance (Hansen and Mowen, 1997).

According to Chartered Institute of Management Accounting (CIMA) UK, there are several types of budgets for a business such as Operating Budget, Cash Budget and Master Budget. Operating Budget are including sales budget, production budget, direct material usage budget, direct material purchase budget, direct labour budget, factory overhead budget and selling and administration budgets. Cash Budget is a detailed budget of estimated cash inflows and cash outflows of the organization. Master Budget consolidates all subsidiary budgets and usually comprises the budgeted profit and loss account, balance sheet and cash flow statement.
For the purpose of this descriptive study, sales budget, purchase budget and administration budget had been chosen as that types of budget is important to the daily operation of the small business.

\section{Problem Statement}

The importance of small businesses to the economic and social has contributed to the development of this study. As a developing country, Malaysia is determined in increasing the nation income and public economy. The small business could act as the supporting pillars as it is the vital to the business environment in Malaysia. As budgeting is very important to the business survival; the small business operator awareness and knowledge in budgeting must be determined. The result from the study could help the government or other responsible agencies in developing possible framework, planning or strategies for the small business.

\section{Objectives of the Study}

There are two main objectives of the study; firstly to determine the awareness level of small business owner/manager on budgeting and secondly to determine the knowledge level of small business owner/manager on budgeting.

\section{Methodology}

As an early survey, a descriptive study is more suitable and had been conducted accordingly. In this study, 160 sets of selfconstructed questionnaire being distributed to the small trader in the state of Selangor. As the first phase of survey, only 160 selected small business owner been approached and they were required to answer the questionnaire in the same time. There are two main sections which is section A and section B. Section $\mathrm{A}$ is the demographic information of the respondents while section B divided into two sections comprised on the questionnaire of awareness or the first section and their knowledge on business budget for the second section. The questionnaire were randomly distributed to the small business in 9 districts of Selangor namely Petaling, Klang, Gombak, Kuala Selangor, Sabak Bernam, Hulu Langat, Kuala Langat and Sepang. Selangor had been chosen as it is the largest populated state in Malaysia amounted 5411324 peoples as in 2010. Five points Likert Scale has been used to determine their level of awareness and knowledge level in budgeting.

\section{Findings}

As mentioned earlier, the respondent for the study were only the small business owner/manager from the state of Selangor. Therefore the variation of respondents profile did not vary very much. About 104 of the respondents are male traders $(65$ percent) and the balance about 56 respondents ( 35 percent) are female traders. This findings is supported in a study by Norfadzillah (1994) when she found the same pattern. About 56.2 percent or 90 of the respondents indicated that their age are more than 36 years while 70 respondents or 43.6 percent are below than 36 years. About 97 respondents (60.6 percent) 
are involved in foods and beverages, 25 respondents (15.6 percent) are baker, 21 respondents (13.1 percent) are tailors, 12 respondents ( 7.5 percent) are barbers and the balance of 5 respondents are mechanics (4.5 percent). For the academic qualifications, 69 of the respondents (43.1 percent) obtained only Sijil Pelajaran Malaysia (SPM), 68 respondents (42.5 percent) with certificate, 13 respondents $(8.1$ percent $)$ are Diploma holder and 5 respondents (3.1 percent) each for Sijil Tinggi Pelajaran Malaysia (STPM) and other qualification. A study by Zaimah (2004) also found most of the small and medium business operator have secondary level qualifications. In terms of business location; 45 respondents ( 28.1 percent) are located in Bangi. 45 respondents (28.1 percent) are located in Bangi. 39 respondents (24.4 percent) are located in Petaling. 20 respondents (12.5 percent) are located in Shah Alam. 19 respondents (11.9 percent) are located in Kuala Langat and the balance are divided failrly between the district of Hulu Langat, Sabak Bernam and Sekincan about 37 respondents.

For the question to know the owner awareness on budget; it was found that 69 of respondents (43.1 percent) answered agree and very agree, while 86 respondents (54 percent) not sure and 5 respondents (3.1 percent) disagree and very disagree. In terms of the importance of budget to their business; 31 of respondents (19.4 percent) answered agree and very agree while 114 respondents ( 71.3 percent) not sure and 15 respondents each disagree and very disagree. For the importance budget preparation, about 30 respondents (18.8 percent) answered agree and very agree, 106 respondents 66.3 percent) not sure while 24 respondents (15 percent) answered disagree and very disagree.

Sales budget, purchase budget and administration expenses budget been chosen to test the knowledge of small business owner on budgeting. For sales budget item estimation, it was found that 71 respondents (44.4 percent) answered agree and very agree, while 71 respondents (44.4 percent) not sure and 18 respondents (11.3 percent) disagree and very disagree.

For purchase budget item estimation; it was found that 54 respondents (33.8 percent) answered agree and very agree, while 93 respondents (58.1 percent) not sure and 13 respondents (8.1 percent) disagree and very disagree.

For administration expenses budget item estimation; it was found that 58 respondents ( 36.3 percent) answered agree and very agree, while 97 respondents (60.6 percent) not sure and 5 respondents (3.1 percent) disagree and very disagree.

Descriptively, the small business owner awareness on budgeting is 100 percent when all 160 respondents answered in moderate pattern (2.34 to 3.66) .For the knowledge of owner on budgeting 132 respondents or 83.5 percent answered in moderate pattern ( 2.34 to 3.66 ) and the balance 28 respondents or 17.5 percent answered in highpattern (3.67 to 5.00). Ahmad Zukni (2000) in his study also found that only a small number of small business owner are practicing the financial management for their business which including budget.

\section{Limitations and Conclusion}

In general, this study is able to achieve it's objectives in order to determine the awareness and knowledge of small businesses owner on budgeting which the pattern either moderate or high. However, there are limitations that were encountered in the study. Due to these limitations, the suggestions for future study will be discussed accordingly. The respondents may have limited time available to answer the questionnaire due to work commitments and time constraint as they have to manage the daily operation of the business as well. This could reduce the accuracy of the data provided. In addition, there are thousands of small business in Selangor, and the study only chose a small sample of them, as a result, the responses received may not represent all the population. Future study is encouraged to eliminate this obstacles, therefore an accurate answer might be established.

\section{References}

Ahmad Zukni Johari, (2000) Ke arah Mempertingkatkan Latihan dan Kemahiran Bumiputera Dalam Perniagaan Agihan, Working Paper, Konvensyen Penyertaan Bumiputera Dalam Industri Perdagangan Pengedaran, 19 - 20 September Kuala Lumpur.

Cress, W.P., and J.B.Pettijohn. 1985. A survey of budget related planning and control policies and procedures. Journal of Accounting Education 3 (2): 61-78.

Hansen, D.R.,and M. M.Mowen. 1997. Management Accounting, $4^{\text {th }}$ Edition, Cincinnati, OH: South Western College Publishing.

John R. Blondal, 2006. OECD Journal on Budgeting, Vol 6 No1. OECD Journal On Budgeting.

Moha Asri Hj Abdullah, Juhary Ali, Faoziah Idris, 2000. Pengurusan Perniagaan Kecil. Kuala Lumpur: Utusan Publications \& Distributors Sdn Bhd.

Norfadzillah Hitam,1994. Bumiputera Entrepreneurship , PhD Dissertation, University of Hawaii, Honolulu.

Welker, R.B., and N. Magner. 1994. The effects of differential perceptions of formal budgetary procedures on effective employee responses. British Accounting Review 26: 27-41.

Zaimah Zainal, 2004, Pembangunan Keusahawanan Peniaga Kecil-kecilan Wanita Luar Bandar, Dissertation for Master Education, Universiti Kebangsaan Malaysia.

www.cgc.com.my

www.cimaglobal.com

www.mara.gov.my

www.miti.gov.my

www.mof.gov.my

www.pns.com.my

www.smebank.com.my

www.smecorp.gov.my

www.tekun.gov.my 